Discussion Paper No. 07-057

\title{
The Globalization of Tax Policy: What German Politicians Believe
}

Friedrich Heinemann and Eckhard Janeba

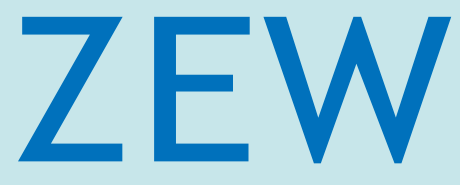

Zentrum für Europäische Wirtschaftsforschung $\mathrm{GmbH}$

Centre for European

Economic Research 
Discussion Paper No. 07-057

\title{
The Globalization of Tax Policy: What German Politicians Believe
}

\author{
Friedrich Heinemann and Eckhard Janeba
}

Download this ZEW Discussion Paper from our ftp server:

ftp://ftp.zew.de/pub/zew-docs/dp/dp07057.pdf

Die Discussion Papers dienen einer möglichst schnellen Verbreitung von neueren Forschungsarbeiten des ZEW. Die Beiträge liegen in alleiniger Verantwortung der Autoren und stellen nicht notwendigerweise die Meinung des ZEW dar.

Discussion Papers are intended to make results of ZEW research promptly available to other economists in order to encourage discussion and suggestions for revisions. The authors are solely responsible for the contents which do not necessarily represent the opinion of the ZEW. 


\section{Non-technical summary}

Theoretical analyses of national tax policy in an environment of globalization assume that political decision makers have an unbiased perception of constraints. In this paper, by contrast, we document a strong ideological bias among policy makers with respect to the perceived mobility of international tax bases, which in turn influences directly and indirectly the perceived national autonomy in tax setting and preferences for policy reform. Our findings are based on an original survey of members of the German national parliament (Bundestag) relating to their views on business tax policy. We document not only an ideological bias in the perception of international mobility of tax bases, but more generally determine the factors that influence the views of policy makers.

The survey was conducted in late 2006 and early 2007, shortly before the Bundestag debated and voted on a company tax reform bill. In the survey we ask questions relating to three possible channels of interaction between globalization and national tax policy, which we call the globalization and tax policy channels: i) the role of real corporate mobility, ii) the extent of international profit shifting, and iii) the role of voters' awareness of tax policy in other countries. The questions correspond to relevant hypotheses identified earlier in the literature, namely tax competition for real investment, tax competition for paper profits, and yardstick competition. In addition, we are interested in the perceived autonomy of German tax policy and the desirability of an EU minimum corporate tax rate.

We analyse the survey data in a two step procedure. In a first step, we ask how the perception of globalization channels is influenced on by the MP's party membership and a number of other control variables. Among the latter are variables measuring the individual MP's education, membership in specialized committees, years in Bundestag and other characteristics. In a second step, we check how the assessment of tax policy autonomy and preferences for minimum taxes in the EU are related to perceived globalization restrictions and other variables among which again party membership receives a special attention.

Our main findings are as follows: First, ideological bias matters in explaining the politicians' views on the three globalization and tax policy channels, and the bias matters quantitatively more than most other control variables such as the politician's profession, membership in economics related parliament committees, years in parliament, and educational degree. For example, there is a clear left-right bias in perception of real corporate mobility in response to taxation. More left-wing politicians believe that taxation plays less of a role in company location decisions than right-wing politicians. We also obtain interesting insights with respect 
to the impact of the election mode by exploiting a particular feature of the German electoral system: About fifty percent of legislators in the German parliament are elected directly in districts, while the other half is elected via a party list, where seats are allocated to parties based on vote shares. Interestingly, party list MPs with arguably less direct contacts to regional constituencies perceive a lower real tax elasticity of companies compared to directly elected politicians.

Second, the yardstick competition hypothesis finds relatively little support in the German Bundestag (see Besley and Case, 1995, for the seminal contribution and empirical evidence for the U.S.). In general, German politicians don't believe that voters care much about other countries' tax policies. Controlling again for the politician's mode of election, however, we find that directly elected politicians believe more strongly in the role of voters' perception of other countries' tax policies.

We get our third main finding when we proceed to explain the perceived degree of national autonomy in tax setting and use the answers to the three previous questions (the channels of globalization and tax policy) as explanatory variables. In addition, we also allow party membership to directly explain the responses by legislators. We find again a strong direct ideological bias. Ideology matters also indirectly, in particular via the profit shifting channel. Hence, party membership matters both directly and indirectly.

Finally, we use the same approach to explain preferences for EU tax harmonization and find that minimum tax rates for companies are more strongly favoured by left wing parties, even after controlling for the three globalization and tax policy channels. The direct ideology effect is quantitatively more important than the three channels of globalization. Perhaps surprisingly, directly elected politicians tend to be more in favour of minimum tax rates.

Several robustness checks indicate that our key results are not distorted by a possible selection bias in the survey and that party membership in the Bundestag has indeed an information content with respect to the MP's tax ideology. 


\title{
The Globalization of Tax Policy: What German Politicians Believe
}

\author{
Friedrich Heinemann (ZEW Mannheim) \\ Eckhard Janeba (University of Mannheim and CESifo)
}

October 2007

\begin{abstract}
The process of globalization has an important impact on national tax policies. Most of the literature on taxation of capital in open economies does not focus directly on the political decision making process and assumes that the desired tax policy is responding to objective underlying tradeoffs. Based on an original survey of members of German national parliament (Bundestag) in 2006/7 we document a strong ideological bias among policy makers with respect to the perceived mobility of international tax bases (mobility of real capital and shifting of paper profits). Ideology via party affiliation influences also directly and indirectly the perceived national autonomy in tax setting and preferences for a EU minimum tax for companies. There seems little consensus as to what the efficiency cost of capital taxation in open economies are, even though our survey falls in period of extensive debate about and actual adoption of a company tax reform bill in Germany.
\end{abstract}

JEL Classification Code: D78, D83, H25

Keywords: Globalization, business taxation, tax competition, beliefs, member of parliament

Friedrich Heinemann

Centre for European Economic Research

(ZEW)

L 7,1

68161 Mannheim

Germany

++49-621-1235 149

Heinemann@zew.de
Eckhard Janeba*

Department of Economics

University of Mannheim

L7, 3-5

68131 Mannheim

Germany

++49-621-181 1795

janeba@uni-mannheim.de.

*Corresponding author

We thank Matthias Hunold and Lars Weddige for excellent research assistance. We benefited from comments by participants of the first annual Summer Symposium at the Oxford University Centre for Business Taxation in 2007 and the members of the DFG priority programme Institutional Aspects of Federal Systems. 


\section{Introduction}

International mobility of capital and firms restricts national tax autonomy and puts pressure on governments to reduce taxes on mobile factors. The enormous literature on international tax competition attests to this hypothesis (see Wilson (1999) for a survey). Empirically, statutory corporate tax rates have substantially declined in many countries over the last 20 to 30 years, while effective tax rates have declined less so due to base broadening measures (Devereux et al. (2002)). How should society change tax policy in response to the increasing international mobility? We might expect that all individuals reduce their desired tax rates on capital because the efficiency cost of taxation have gone up, but the desired level of taxation should vary by individual, perhaps due to differences in preferences over an equity-efficiency trade off. ${ }^{1}$ A person with little capital income may favour a higher tax on capital than a person with little capital income (see Persson and Tabellini, 1992, for a tax competition model with heterogenous voters, and Meltzer and Richard, 1981, for a closed economy model on equilibrium redistribution when individuals differ in income). Yet, the efficiency costs of levying taxes on mobile factors are assumed to be objective.

In this paper, by contrast, we document a strong ideological bias among policy makers with respect to the perceived mobility of international tax bases, which in turn influences directly and indirectly the perceived national autonomy in tax setting and preferences for policy reform. In contrast to previous literature there seems little consensus as to what the efficiency cost of capital taxation in open economies are. Our findings are based on an original survey of members of the German national parliament (Bundestag) relating to their views on business tax policy. We document not only an ideological bias in the perception of international mobility of tax bases, but more generally determine the factors that influence the views of policy makers. Our survey identified the name of the member of parliament (MP) and hence we condition the results on various control variables such as education and information available to policy makers. Overall, our paper raises important questions about the way economists model tax policy decision making. The survey approach appears also fruitful in studying the empirical validity of hypotheses regarding tax policy decisions in open economies.

The survey was conducted in late 2006 and early 2007. While not all members of parliament can be expected to be specialists on tax policy, reform of company taxation was put high on the agenda by the grand coalition governing Germany since late 2005. For this reason various tax reform proposals were discussed in the public during 2005-7 and a specific busi-

\footnotetext{
${ }^{1}$ This assumes that there is some reason to levy a positive tax on capital in an open economy, for example, because the country is large or pure profits are captured by the tax.
} 
ness tax reform bill was passed by the Bundestag a few months after our survey in May 2007. The timing of our questionnaire falls thus in a period of general awareness about the international dimension of tax policy. The reason for the present government's priority of reforming company taxation is the high level of taxation in Germany, despite an earlier reform under the previous government that already lowered the tax burden for corporations and noncorporations. Both in terms of statutory and effective marginal corporate tax rates Germany ranks highest among EU countries, and after the Eastern enlargement of the EU Germany borders or is close to countries with much lower tax rates (see for example Devereux et al., 2002, and for more recent data Haufler, 2006). Huizinga and Laeven (2007) suggest that profit shifting by multinational companies is indeed a major problem in Europe, and in particular for Germany, whose fiscal revenue losses are estimated to be about 3.5 billion Euros.

In the survey we ask questions relating to three possible channels of interaction between globalization and national tax policy, which we call the globalization and tax policy channels: i) the role of real corporate mobility, ii) the extent of international profit shifting, and iii) the role of voters' awareness of tax policy in other countries. The questions correspond to relevant hypotheses identified earlier in the literature, namely tax competition for real investment, tax competition for paper profits, and yardstick competition. In addition, we are interested in the perceived autonomy of German tax policy and the desirability of an EU minimum corporate tax rate.

Our main findings are as follows: First, ideological bias matters in explaining the politicians' views on the three globalization and tax policy channels, and the bias matters quantitatively more than most other control variables such as the politician's profession, membership in economics related parliament committees, years in parliament, and educational degree. For example, there is a clear left-right bias in perception of real corporate mobility in response to taxation. More left-wing politicians believe that taxation plays less of a role in company location decisions than right-wing politicians. However, the ideological bias is not always monotonic. For instance, members of the center-left Social Democrats (SPD) believe that international profit shifting is much more prevalent than more right wing or liberal parties such as the center-right Christian Democrats (CDU/CSU) and market-oriented Free Democrats (FDP). We also obtain interesting insights with respect to the impact of the election mode by exploiting a particular feature of the German electoral system: About fifty percent of legislators in the German parliament are elected directly in districts, while the other half is elected via a party list, where seats are allocated to parties based on vote shares. Interestingly, party 
list MPs with arguably less direct contacts to regional constituencies perceive a lower real tax elasticity of companies compared to directly elected politicians.

Second, the yardstick competition hypothesis finds relatively little support in the German Bundestag (see Besley and Case, 1995, for the seminal contribution and empirical evidence for the U.S.). In general, German politicians don't believe that voters care much about other countries' tax policies. Controlling again for the politician's mode of election, however, we find that directly elected politicians believe more strongly in the role of voters' perception of other countries' tax policies.

We get our third main finding when we proceed to explain the perceived degree of national autonomy in tax setting and use the answers to the three previous questions (the channels of globalization and tax policy) as explanatory variables. In addition, we also allow party membership to directly explain the responses by legislators. Political economy considerations suggest that through the personal interest of a politician (e.g., high own capital income) party affiliation could matter if party membership were highly correlated with capital income. We find again a strong direct ideological bias. Ideology matters also indirectly, in particular via the profit shifting channel. Hence, party membership matters both directly and indirectly.

Finally, we use the same approach to explain preferences for EU tax harmonization and find that minimum tax rates for companies are more strongly favoured by left wing parties, even after controlling for the three globalization and tax policy channels. The direct ideology effect is quantitatively more important than the three channels of globalization. Perhaps surprisingly, directly elected politicians tend to be more in favour of minimum tax rates.

Several robustness checks indicate that our key results are not distorted by a possible selection bias in the survey and that party membership in the Bundestag has indeed an information content with respect to the MP's tax ideology.

Our work relates to several other literatures (other than the tax competition literature mentioned above). Our research is complementary to Hanson, Scheve et al. (2005) and Mayda and Rodrik (2005) who are interested in the determinants of views on globalization. In contrast to our work, however, they focus on immigration and trade policies, respectively, and have only private households in their samples. Our survey of policy makers is novel and interesting because policy makers tend to be better informed than most households and are more directly involved in actually choosing policies. The second literature to which we relate deals with the formation of beliefs about economic policies in general. Caplan (2002) and Blinder and Krueger (2004) also emphasize the role of ideology which is based on survey evidence from households and economists. Finally, the role of misconceptions and voter ignorance is 
explored in explaining views on domestic tax policy in the U.S., such as Krupnikov et al. (2006) and Birney et al. (2006) on the repeal of the estate tax, and Slemrod (2003) on the replacement of the income tax by a flat or retail sales tax.

Our paper is structured as follows. In the next section we provide relevant information relating to the German electoral and political system and the debate about company tax reform. We describe the survey and provide a summary of the descriptive data in section 3 . In section 4 we present the structure of a simple two step approach in the formation of tax policy opinion and the estimation methodology. Subsequently, we turn in section 5 to our key findings. Various robustness checks are analyzed in section 6 before we conclude with ideas for future work.

\section{Institutional background}

In this section we provide useful information on two items relating to our survey: first the German electoral and political system, and second actual company tax reform in Germany.

\section{German electoral and political system}

Germany is a parliamentary democracy. The parliament consists of two chambers, the lower house (Bundestag) and the upper house (Bundesrat), the latter representing the 16 states of Germany. The Bundestag elects the chancellor and thus controls the executive. Our survey is based on members of the Bundestag. The parliament consists of (at least) 598 members, who are elected every four years. There are 299 districts, and each district is represented by one person. The other half of the parliament is elected based on vote shares for party lists. We exploit this unique difference in election mode in our empirical analysis below. To be more specific, each voter has two votes. The first vote is for the preferred candidate of his/her district, and the district representative is chosen using plurality rule. In most districts, the elected representative is from one of the two large parties (Social Democrats or Christian Democrats). The second vote is for a party (list). The overall seat allocation in parliament is based on national vote shares of the second vote (e.g., proportional representation) subject to the requirement that a party needs to catch at least $5 \%$ of the national vote or win three districts.

A peculiarity of the German electoral system is that the share of the second vote determines the share of total seats in parliament, even if a party has won more districts (based on the first vote) than it should obtain based on the second vote. For this reason additional seats 
("excess seats") are granted to a party that has won more districts (from the first vote) than its proportional vote share would suggest. In the current German parliament (electoral period 2005-9) initially there have been $614(=598+16)$ seats due to 9 excess seats for the Social Democrats and 7 for the Christian Democrats. ${ }^{2}$

Broadly speaking parties can be characterized as follows: The Christian Democrats (CDU/CSU) are a centre-right party, while the Social Democrats (SPD) represent the centreleft. The Free Democrats (FDP) are liberals in the sense of favoring a small government and low taxes, which makes them more market friendly than the Christian Democrats, who in turn are more market-oriented than the Social Democrats. The Left Party is drawing heavily on former communists in East Germany and disappointed Social Democrats from the left wing in West Germany. On economic policies the Left Party is to the left of the SPD. The Greens heavily focus on environmental and social issues, and are popular with relatively young, well educated people from the middle class. Party members have quite different views on economic policies though, ranging from market friendly and a preference for sustainable budgets to fairly interventionists views.

\section{Company tax reform in Germany}

In Germany tax rates on capital income, in particular corporate income, are high by international standards. For example, the nominal tax burden on retained profits in 2006 is about $37 \%$, consisting of a $25 \%$ corporate tax rate plus local tax and the so-called solidarity charge. This makes Germany a high tax country among OECD and EU countries. A similar picture arises with respect to effective marginal tax rates (see Haufler, 2006, for recent data). For this reason the current government made up by Social Democrats and Christian Democrats agreed to reform company taxation after establishing the grand coalition in November 2005. The major objective of the government has been to make Germany's tax system more competitive internationally, in particular for domestic and foreign investors in real capital. At the same time, there is fear about the shifting of paper profits out of Germany by multinational firms through means of transfer pricing and thin capitalization, and thus rules for securing tax revenues in Germany are aimed at.

Shortly after our survey the grand coalition of Christian and Social democrats presented a company tax reform bill (Deutscher Bundestag, 2007a) in the spring of 2007 to the Bundestag, which is based on the coalition agreement from 2005 and an initial draft in 2006. The tax reform bill changes twelve major laws all relating to company taxation and the taxa-

\footnotetext{
${ }^{2}$ Excess seats are lost when a MP withdraws from the Bundestag. Due to such an incidence the number of seats declined from 614 to 613 in June 2007.
} 
tion of capital income, and thus is a major and complex legislation. The main items of the bill, as relevant for the context of our survey, are the following:

- Reduction of nominal tax burden for retained profits by corporations from almost 39\% to $29,83 \%$, mostly by a reduction of the corporate tax rate from 25 to $15 \%$. A similar reduction for retained profits of non-corporations is contained.

- Provisions regulating the extent of interest deductibility of loans. Multinational firms can deduct interest on intra-company loans fully only if the difference between interest paid and interest received is less than one 1 million Euros. Any excess can be expensed only at a lower rate and/or carried forward.

- Various provisions relating to the definition of the corporate tax and local tax (Gewerbesteuer), some benefiting other hurting firms overall. On net the marginal effective tax rates are intended to fall.

- The overall fiscal revenue loss is estimated to be $€ 5$ billion annually in the long run (static effects, no behavioural adjustment assumed).

The bill was passed with minor modifications by the Bundestag on May 25, 2007, and the upper house (Bundesrat) representing the state government on July 6, 2007 (Deutscher Bundestag, 2007b). The new law will become effective on January 1, 2008. Of the majority coalition parties, two members of the Christian democrats abstained, while all others voted in support. For the Social Democrats two opposed the bill and 15 abstained. The three smaller parties all voted against the bill, albeit for very different reasons. The FDP supports the reduction in the corporate tax rate, but believes that the reform is too complex, the benefits for noncorporations are too low and non-transparent, and the overall net reduction in company taxes is too small to have an impact. The exact opposite view is taken by the Left Party who views the tax bill as a major gift to large corporations and capital owners at the expense of low and middle income workers. The Green Party fears that the revenue impact is entirely unclear, non-corporations do not benefit enough, and various provisions will reduce rather than stimulate investment. 39 Members of Parliament were not present on the day of the vote.

\section{Survey and Data}

The survey among the members of the German Parliament (Bundestag) started in November 2006 and the last responses were recorded in February 2007. The legislators were addressed 
by written letters and subsequently by phone calls (when no initial response). 157 members of the German Bundestag participated by returning filled questionnaires resulting in a response rate of 25.6 percent with substantial differences across parties (see Table 1). Possible concerns about the differential response rate are addressed in our estimation approach and subsequent robustness checks.

The questionnaire included the following questions (original questions in German are available upon request):

The Globalization and Tax Policy Channels:

- Question 1 (Q1) on real corporate mobility: "The level of company taxation is mentioned as one factor for the location decision of companies. How important do you believe is the level of company taxation in this context?"

- Question 2 (Q2) on profit shifting: “Reports suggest that companies use tax planning strategies to shift paper profits from high-tax to low-tax jurisdictions. How widespread do you think is this phenomenon?"

- Question 3 (Q3) on voter awareness: "Do you believe that voters consider tax rates in neighboring countries when forming an opinion on the appropriate level of company taxation in Germany?”

\section{Policy Questions:}

- Question 4 (Q4) on national autonomy: "Some people feel that globalization leads to a loss in national autonomy. Do you think that Germany still has any autonomy in the area of company taxation?”

- Question 5 (Q5) on EU minimum tax: "In the current debate some have suggested that the EU should introduce a minimum tax for companies. Are you in favour of this proposal?”

Answers could be given on a discrete scale from 1 ("not at all”) to 9 (“very much”).

The survey was conducted non-anonymously so that individual characteristics of respondents could be identified, although non-anonymity may impact negatively on the honesty of answers. However, confidentiality of individual responses was guaranteed. Furthermore, a certain "hiding bias" should not distort the results if one assumes that it is not systematically correlated with other variables of interest. 
Apart from party membership as the key variable for a MP's ideological position we took account of variables related to a member's education, her level of specialized information and a group of further variables as summarized in Table 2. This information was compiled from the Bundestag website ${ }^{3}$. While the precise classification of variables is debatable, in particular the distinction between education and information variables, the classification is helpful in our view. Education should be relevant for the ability to process information, and the educational specialization (e.g., on economics or business) should hint towards the degree of information about globalization restrictions. Similarly we would expect that certain professional experience (e.g. as a self-employed), the length of Bundestag membership, and the membership in specialized Bundestag committees serve as useful proxies for the degree of information on the tax policy environment.

Among other variables we include dummies to differentiate between Eastern and Western German, male and female, direct and party list MPs. We also account for age. The heterogeneity of the economic and political environment in Eastern and Western Germany may impact results also because Eastern Germans have a different view on the role of the state (Alesina and Fuchs-Schündeln, 2007). Empirical studies have also pointed to a significantly different focus of female representatives compared to their male colleagues: Female legislators tend to have different policy priorities and are more likely to express concerns about social policy issues (Thomas, 1994; Seltzer et al., 1997). Hence, gender may be taken as a proxy for the specific policy specialization and, hence, interest for and information on tax issues. Finally, MPs elected directly in a district and not through a party list may have more direct contact with citizens and companies which could be relevant for the perception of globalization constraints. ${ }^{4}$

As pointed out in the introduction personal interests may well influence opinion. For this reason we also experimented with an additional variable that relates to income of legislators other than their uniform compensation for their status as member of parliament. This side income ("Nebeneinkünfte") of MPs originates from occupations unrelated to the seat in Bundestag such as self-employment, membership in company supervisory bodies, paid speeches or other. Revenues from these activities are legal for German MPs, but - following a ruling of German's constitutional court in summer 2007 - have to be published. Unfortu-

\footnotetext{
${ }^{3}$ www.bundestag.de which also presents the MP's curricula vitae.

4 The distinction between the two types of members of parliaments is somewhat blurry in so far as MPs elected via the party list are sometimes candidates in a district and were not elected. We also experimented with a modified party list variable taking account of the relative position of the MP on a party list relative to the maximum number of places on the list which in the election 2005 qualified for a seat in Bundestag (results not reported). This relative position did not prove to be important.
} 
nately, the publication requirement is limited and requires information about income in three intervals so that the quality of the resulting data is relatively poor. This may explain that an inclusion of a side income variable did not have significant results, although from a theoretical point of view this variable could be a proxy for private interests or information aspects with respect to corporate tax policy.

Finally, we also included basic economic characteristics of the individual MP's federal state in order to allow for special interests related to a constituency's specific needs.

A first look at the descriptive data reveals that there is a strong correlation between ideology measured on the basis of party affiliation and the answers to the five questions (Table 3). ${ }^{5}$ With the exception of the voter awareness question (Q3) responses to all questions differ by party affiliation. This outcome may not come as a complete surprise when normative issues such as the desirability of a EU minimum tax on companies is considered. However, the strong correlation of perceived globalization restrictions and ideology is harder to explain and may hint to an ideological bias in information processing, as it has been shown to be virulent in the population at large for the perception of economic issues in general (Blinder and Krueger, 2004; Caplan, 2002). In the following we dig deeper into this question by disentangling the ideological impact on globalization views from other influences related to education, information and the other individual characteristics of Bundestag members.

\section{The formation of tax policy opinions and estimation approach}

The rational formation of tax policy opinions can be described as a two step procedure. In a first step, decision makers collect information on the tax policy environment. With regard to globalization this relates to an assessment of three channels: first, the tax elasticity of real investment $(R I)$, second, the tax elasticity of paper profits $(P P)$ and third, the reaction of voters to tax developments abroad i.e., yardstick competition $(Y C)$. In a second step, decision makers choose the tax policy which maximizes their specific objective function. For example, they vote for minimum taxes $(M)$ or they decide to which extent they stick to an autonomous tax policy $(A)$ even at a cost of increasing outward mobility.

Ideology (IDE) should directly influence the second step following conventional theory. Representatives with different subjective equity-efficiency trade-offs should have different tax policy preferences even if they fully agree on the relevance of the three globalization

\footnotetext{
${ }^{5}$ In section 6 we address the link between ideology and party membership in detail.
} 
and tax policy channels (e.g., see the standard Meltzer-Richard (1981) model of redistributive taxation in a closed economy). We would not expect that the perception of restrictions is also influenced by ideological views however.

The appropriateness of these expectations on the impact of ideology is now tested within the following set-up: To analyze the formation of beliefs on tax policy restrictions under globalization - the first step - models of the following type are considered:

$$
\begin{aligned}
& \text { (1a) } P_{R I}=f(E D U, I N F, \text { OIN, STC, IDE) } \\
& \text { (1b) } P_{P P}=f(E D U, I N F, \text { OIN, STC, IDE) } \\
& \text { (1c) }
\end{aligned}
$$

The perception $P$ of each of the three channels may be influenced by the individual MP's education $E D U$, his or her availability of objective information INF, other individual characteristics OIN, and particular economic characteristics of the legislator's state STC as suggested above. If the usual modelling of rational formation of tax policy opinions is correct, however, ideology IDE should have no influence in the first step.

In a second step the formation of tax policy opinions is finalized by translating the perceived restrictions into preferred policy options, which in turn depend on an individual's objective function. Here we would expect that decision makers with similar perceptions of restrictions should tend to see more room for an autonomous tax policy if they put a relatively large weight on equity relative to efficiency. Similarly, the preference for minimum taxes should not only be influenced by the perceived restrictions but also by ideology because minimum taxes tend to offer more room for redistributive objectives. To test for the relative role of ideology in the second step, models of the following types are considered:

$$
\begin{aligned}
& \text { (2a) } \quad A=f\left(P_{R I}, P_{P P}, P_{Y C}, E D U, I N F,\right. \text { OIN, STC, IDE) } \\
& \text { (2b) } \quad M=f\left(P_{R M}, P_{P P}, P_{Y C}, E D U, I N F,\right. \text { OIN, STC, IDE) }
\end{aligned}
$$

The belief in tax autonomy (A) and the preference for an EU minimum tax (M) are modelled as a function of the perceived restrictions and of ideology directly. The impact of education, influence and other individual characteristics is included in the second step of formation of tax policy positions. 
Our survey of the members of the German Bundestag allows us to test for the described structure in the formation of tax policy opinions. We proceed by estimating ordered probit models for the answers Q1-Q3 representing the perceived restrictions according to the first step equations (1a)-(1c). We then continue by analyzing the second step by estimating ordered probit models for the answers to Q4 (related to equation 2a) and Q5 (equation 2b).

Several standard problems of econometric testing of survey data have to be addressed (see Hanson et al., 2005 or Mayda and Rodrik, 2005, for similar approaches): The highly different response rates of different parties point to a selection bias which could influence estimation results. Therefore, we estimate weighted ordered probit models, where weights correct for the sample's lacking representativeness. Our weights are based on two strata of the sample: party membership and years in Bundestag which both are highly significant in a nonresponse analysis. Even these measures cannot exclude that a selection bias can still in principle contaminate the results and we return to this issue in section 6 .

Furthermore the descriptive analysis indicates that the variance of answers differs widely between parties. To cope with the resulting problems we allow for party clustered error terms, i.e. the usual assumption of uncorrelated error terms is given up for observations from the same party. As a consequence, our estimation procedure is robust against unobserved variables or structures which lead to a larger homogeneity of answers within one party.

The specification included the proxies for education, information, other individual characteristics and economic structure as they are listed in section 2.

\section{Results}

\section{First step results}

Estimation results for the three first step model reveal a different overall fit of the models (Table 4). Whereas estimations show reasonable properties for the perception of real mobility and profit shifting, the estimation for yardstick competition has hardly explanatory power. There is support for the relevance of information proxies and less for the importance of education. Economic state characteristics do not show up significantly apart from a weakly significant impact of the unemployment rate in the yardstick competition equation. These results indicate that belief formation on German tax policy is not clearly linked to special interests of a MP’s constituency. 
Among the information variables memberships in the financial committee responsible for tax policy, the length of Bundestag membership and professional experience as selfemployed lawyer, tax consultant etc. ("Freiberufler”) clearly influence the perception of the tax mobility environment. The MPs with a professional background as self-employed tend to stress the importance of paper profit mobility, while they regard real mobility as less important compared to their colleagues among the members of Bundestag. Members of the financial committee who should - with regard to tax policy - be the best informed members of Bundestag tend to stress real mobility as a relevant restriction. The same holds for those MPs with a longer tenure in the Bundestag. The other variables - Eastern/Western German, gender, party list and age - also turn out to be important although to a different degree for the three channels. Female members assess globalization restrictions to be more severe compared to their male colleagues. Eastern German MPs have fewer concerncs about profit shifting. Party list MPs assess real mobility and yardstick competition as less pronounced than MPs voted into the parliament directly by a district - a plausible result given the fact that district representatives should have more salient experience with company decision making.

Beyond these detailed findings, however, the essential result is the clear and overwhelming impact of ideology on the perception of globalization restrictions. Thus, the finding of the descriptive data analysis (Table 3) is obviously no statistical artefact and is strongly supported in the multivariate model. Ideology measured on the basis of party membership is not only highly significant. Judged on the size of marginal effects (for each question evaluated at the most frequent answer category) party membership also outweighs the impact of information, education or other variables where these ideological marginal effects are particularly pronounced for real mobility. It is striking that the ordering of party effects for the perception of real mobility corresponds to the left right spectre: Compared to the liberal FDP the parties regard real mobility of companies the less important the further left their political orientation is. Our results strongly reject the hypothesis that ideology is unimportant in the first step of opinion building. Hence, our results challenge the key assumption of standard models of tax policy decision making, in which an objective mobility of tax bases is assumed.

\section{Second step results}

The results for the estimation of ordered probit models for answers to Q4 (autonomy) and Q5 (minimum taxes) are presented in Table 5. Based on models (2a) and (2b) we would expect that two classes of variables are important: on the one hand the perceived globalization re- 
strictions and on the other hand individual characteristics linked to a MP's education, information, her state's economic characteristics and ideology.

The regression diagnostics show a good fit, as both models show a high share of correct classifications. The first surprising result of the second step results is the loose link between perceived restrictions on the one hand and the perception of tax autonomy and the minimum tax preference on the other hand. Among the three globalization channels only perceived paper profit mobility is significant in both equations. As expected, a larger perceived profit shifting is associated with less autonomy and a larger preference for minimum taxes. Real mobility is weakly significant in the autonomy equation but with a surprising sign: Perception of high real mobility is associated with a more autonomous assessment. Education variables are significant: a degree qualifying for university entry is associated with a perception of less autonomy and less marked preferences for tax harmonization. Interestingly, a university degree increases the perceived autonomy. Information variables have more importance for the view on harmonization than on autonomy. With more years in the Bundestag the preferences for minimum taxes decline. Perhaps not surprisingly, members of the budgetary committee see more autonomy compared to other MPs. Apart from that they are characterized by more scepticism towards EU minimum taxes. Formerly self-employed "Freiberufler" have a stronger tendency to favour minimum taxes. Among the other variables only the Eastern Germany and the party list dummy are significant: MPs directly elected by a district show significantly larger sympathy for minimum taxes, representatives from the Eastern part of the country see less autonomy. State characteristics are of importance in the minimum tax model insofar as MPs both from relatively wealthy states and states with high unemployment prefer minimum taxes more than others.

The essential result with respect to the impact of party membership is again its high significance. While the size of marginal effects for party membership in the autonomy equation is comparable to the other types of variables, party affiliation by far outweighs the others in the explanation of tax harmonization preferences. The impact of ideology in the second step is less surprising compared to the first step results because subjective equity-efficiency trade-offs should influence the formation of tax policy opinions for a given perception of restrictions. 


\section{Robustness}

We argued above that ideology strongly affects the perception of tax competition channels. An essential question is whether party membership in our survey is really a good proxy for ideology. Two kinds of problems have to be discussed, first with respect to the nature of parties and the belief formation within parliamentary party factions and, second, with respect to the technical issue of selection bias in our survey.

\section{Belief formation within a party faction:}

For a legislator party membership is a variable representing a complex set of issues. For example, Murphy and Shleifer (2004) suggest that parties can be regarded as social networks which allow for an easy influence on opinions of network members. Party members and legislators from a specific party in particular could thus be the victims of party manipulation activities. Thus it is unclear whether the statistical significance of party membership is really the consequence of deeply rooted ideology and resulting psychological process of information filtering or the consequence of party information processes. An example in the context of the German company tax reform is the Social-Democratic finance minister Peer Steinbrück’s strategy to cope with resistance in his party and trade unions against tax cuts for companies. In reaction to this he stressed the base broadening elements of the reform as a means to fight paper profit mobility ${ }^{6}$. Thus, the argument of high paper profit mobility was highly present in the SPD's reform debate. In this sense, the concern of social-democratic legislators about profit shifting (Table 3, Table 4) could to a certain extent mirror the effect of this information campaign.

Furthermore, the individual MP is heavily dependent on the support of his party for his further career prospects. Hence, the impact of party membership as measured in our analysis may represent phenomena like group dependence, loyalty or information biases and is therefore no undistorted proxy for ideology. Even though in our survey confidentiality was assured and even though such a survey is much less prone to loyalty distortions compared to studies of actual behaviour in roll call votes there could distorting effects cannot be excluded.

\footnotetext{
${ }^{6}$ In a typcial statement addressing his party members Steinbrück argues: "Through tax cuts and targeted measures against profit shifting this reform will provide a constant decrease of the fairness gap between profits realized in Germany and profits actually taxed” (Steinbrück, 2007).
} 


\section{Selection bias}

On a technical level, the identification of ideology on the basis of party membership may be impeded by a selection bias. Highly different response rates between party factions (see Table 1) imply the risk that party membership could simply mirror the effect of hidden variables having an impact on participation in the survey. Therefore, without further checks we cannot be certain that our party membership variable truly reflects ideology.

\section{Control group results}

As a first approach to check the importance of both caveats we conducted an identical survey among a control group of economics students at the University of Mannheim in February 2007. In addition to five questions explained in section 3, students were asked to reveal their party preferences. The survey was conducted anonymously. Obviously, loyalty considerations, political career aspects or specific information networks do not play a role for this control group. Thus, the resulting data allow to check for the link between ideology and globalization perceptions because party preference is a more unambiguous proxy of ideology than in the case of the Bundestag. As information proxies we included two questions: One for the number of semesters which the student has already been studying economics and a second question whether the student had already attended an introductory public finance lecture. Among other individual characteristics the respondents were asked to indicate gender and nationality (German/non-German).

Tables 6 and 7 present the results for the three tax competition channels (model 1a, 1b and 1c) and the second step regressions (model 2a and 2b) for the control group. Similar to the survey among legislators the real mobility and paper profit equations perform better than the yardstick competition equation. Again party association has a highly significant impact on the perception of competition phenomena. For real mobility, even the ordering of the party impact is identical to the Bundestag results: The further left is the party preference the lower is the importance assigned to real mobility. For paper profit mobility the ordering of party effects is quite different however: While individuals with preference for the SPD the effect is not significant different from those who favour the liberal FDP (our reference case), students who prefer the other parties perceive less paper profit mobility compared to the FDP supporters. For the Bundestag, the governing parties SPD and CDU/CSU are characterized by a particularly high awareness of paper profit mobility. For the second step results it is striking that perceived restrictions do not appear to be linked at all to the autonomy perception or the pref- 
erence for minimum taxes. Thus, the surprising result of a weak impact of restrictions relative to ideology in the second step is even reinforced by the control group results.

Taken together the control group results provide reassurance that the key Bundestag results about the impact of ideology in both steps are no statistical artefact caused by either party faction effects or a selection bias in the Bundestag survey. However, the different ordering of party effects in the paper profit equation indicates that the Bundestag party effect is to a certain extent also influenced by specific information processes within the parliament.

\section{Party membership and ideology}

So far we assumed that party membership reflects ideology. As a further check for the genuinely information content of our Bundestag party variable with regard to ideology we now make use of a sixth survey question on the role of corporate taxation for equity.

- Question 6 (Q6) on equity: "At a general level, do you think that taxation of companies is important from an equity perspective?”

This question is neither related to the perception of tax competition nor to specific tax policy preferences and targets at a rather pure ideological assessment. We relate the answers to Q6 and party membership in an analogous model framework to models 2a/2b. Table 8 presents the results where party effects are not only highly significant but their marginal effects are also dominating all other effects by far. This impressively underlines the link between party membership and general tax ideology in line with the left-right ordering of political parties: Compared to the market-oriented FDP point of reference all party effects are highly significant where the emphasis on equity is the stronger the further left is the party in the political spectre. Reinforcing our control group insights the result makes us very confident in ruling out a selection bias that contaminates the party membership variable and render it useless as an ideological proxy.

\section{Estimating the first step without ideological variables}

As a final robustness check, Table 9 reproduces the first step regressions (models $1 \mathrm{a}, 1 \mathrm{~b}, 1 \mathrm{c}$ ) but drops the party affiliation dummy. This check allows us to assess the additional explanatory power of party affiliation given possible collinearity between individual characteristics of legislators and party affiliation. For example, compared to their colleagues market-oriented legislators from the FDP have significantly more often a degree in economics/business or ex- 
perience as self-employed. Similarly, representatives of the Left Party are more often from Eastern Germany than from Western Germany. This raises the question as to whether the pure party effect contributes significantly to the overall fit of the model. Our evidence strongly suggests that party effects are important. In all regressions the joint significance of party variables is always highly significant. Moreover, the reduced regressions also point to a significant improvement of the models through the inclusion of party dummies albeit not for all three channels of tax competition. For real mobility and paper profit mobility the drop of party variables leads to a deterioration in the goodness of fit including the share of correct classifications. The deterioration is extremely strong in the real mobility equation (drop from 0.26 to 0.17 ). By contrast, the predictive power of the model does not suffer from dropping party membership in the case of the yardstick competition equation. This confirms our insight that yardstick competition is not an issue in the view of Bundestag legislators.

\section{Conclusion}

To the best of our knowledge this is the first paper to survey the opinions of policy makers with respect to tax policy at a time of increasing international integration. Policy makers are an interesting group to consider, as they actually vote on policies directly and probably are better informed than average citizens. The survey of German legislators was done at a time when tax policy reform was high on the agenda and a few months after the survey the Bundestag actually voted on a reform bill that will lower the statutory and effective tax rates on companies in Germany. The main finding of our analysis is the identification of a strong ideological bias in the legislators' views on the interaction between globalization and tax policy. Our analysis suggests that the perceived efficiency cost of taxation in open economies differ systematically. This is clearly in contrast to how economists have modelled decision making on tax policy in the past.

One caveat is important. At this point we are unable to identify the precise mechanism which is responsible for the strong impact of ideology. The insights from the perception of paper profit shifting indicate that specific information networks or campaigns could have an impact in shaping party members' views. Nevertheless our key result for a strong impact of ideology in the perception of globalization remains valid even if we are not yet able to identify the precise mechanism. 
Future research should attempt to overcome our incomplete understanding of the different perceptions. One way to tackle the issue is to get more information from the policy makers themselves, for example, by asking them how they form their opinion. We did not pursue this possibility with the legislators from the German Bundestag, as it proved fairly difficult to get them to answer just our six questions. We expect more willingness to participate when policy makers from lower level of governments are surveyed. In this context we plan to survey policy makers from competing jurisdictions and to compare their perceived degree of competition with estimates from a strategic interaction model where actual tax rates are the key endogenous variables. This approach would allow us to find independent confirmation for or modification of existing theories of fiscal competition.

\section{References}

Alesina, A.F. and Fuchs-Schündeln, N. (2007). “Good bye Lenin (or not?): The Effect of Communism on People`s Preferences”, American Economic Review 97(4), 15071528.

Besley, T. and A. Case (1995). "Incumbent Behavior: Vote Seeking, tax setting and yardstick competition.” American Economic Review 85, 25-45.

Birney, M., M.J. Graetz, and I. Shapior (2006). "Public Opinion and the Push to Repeal the Estate Tax.” National Tax Journal 59(3), 439-461.

Blinder, A. S. and A. Krueger (2004). "What Does the Public Know about Economic Policy, and How Does It Know It?" Brookings Papers on Economic Activity (1:2004): 327397.

Caplan, B. (2002). "Systematically Biased Beliefs about Economics: Robust Evidence of Judgemental Anomalies from the Survey of Americans and Economists on the Economy." The Economic Journal 112: 1-26.

Deutscher Bundestag (2007a). Entwurf eines Unternehmensteuerreformgesetzes 2008, Drucksache 16/4841, March 27, 2007.

Deutscher Bundestag (2007b). Stenografischer Bericht der 101. Sitzung vom 25. Mai 2007, Plenarprotokoll 16/101.

Devereux, Michael B., Rachel Griffith and Alexander Klemm. (2002). "Corporate income tax reforms and international tax competition.” Economic Policy 35, 449-496.

Hanson, G. H., K. F. Scheve, et al. (2005). Public finance and individual preferences over globalization strategies. NBER Working Paper No. 11028.

Haufler, A. (2006). Die Besteuerung multinationaler Unternehmen. University of Munich, Discussion Paper 2006-21.

Huizinga, H. and L. Laeven (2007). International Profit Shifting within European Multinationals, CEPR Discussion Paper 6048. 
Krupnikov, Y., A.S. Levine, A. Lupia, and P. Markus (2006). "Public Ignorance and Estate Tax Repeal: The Effect of Partisan Differences and Survey Incentives.” National Tax Journal 59(3), 425-437.

Mayda, A. M. and D. Rodrik (2005). "Why are some people (and countries) more protectionist than others?" European Economic Review 49: 1393-1430.

Meltzer, A. and S. Richard (1981). "A rational theory of the size of government.” Journal of Political Economy 89, 914-927.

Murphy, K.M. and Shleifer, A. (2004). “Persuasion in Politics.” American Economic Review, Papers and Proceedings, 94(2), 435-439.

Persson, T. and G. Tabellini (1992). "The Politics of 1992: Fiscal policy and European Integration.” Review of Economic Studies 59, 689-701.

Seltzer, R.A., Newman, J. and Voorhees Leighton, M. (1997). "Sex as a political variable: Women as candidates and voters in U.S. elections.” Lynne Rienner Publishers Inc.

Slemrod, J. (2003). “The role of misconceptions in support of regressive tax reform.” University of Michigan, November 3, 2003.

Steinbrück, P. (2007). "In Deutschland investieren." Communication on the SPD Website, 30.03.2007, www.spd.de/menu/1710203/.

Thomas, S. (1994). “How women legislate.” Oxford University Press, New York.

Wilson, J.D. (1999). “Theories of Tax Competition.” National Tax Journal 52, 269-304.

Table 1: Response rate by party in the Bundestag

\begin{tabular}{|l|c|c|c|}
\hline Party & Number of seats & Responses & Response rate \\
\hline CDU/CSU & 225 & 53 & $\mathbf{2 3 , 5 6}$ \\
\hline SPD & 222 & 33 & $\mathbf{1 4 , 8 6}$ \\
\hline FDP & 61 & 32 & $\mathbf{5 2 , 4 6}$ \\
\hline Left Party & 53 & 27 & $\mathbf{5 0 , 9 4}$ \\
\hline Alliance 90/The Greens & 51 & 12 & $\mathbf{2 3 , 5 3}$ \\
\hline Members without fraction & 2 & 0 & $\mathbf{0 , 0 0}$ \\
\hline Total & $\mathbf{6 1 4}$ & $\mathbf{1 5 7}$ & $\mathbf{2 5 , 5 7}$ \\
\hline
\end{tabular}


Table 2: Variable definitions

\begin{tabular}{|c|c|c|}
\hline Variable & Unit & Explanations \\
\hline \multicolumn{3}{|r|}{ Education variables } \\
\hline Abitur & Dummy & Secondary qualification for university entrance \\
\hline Tertiary degree & Dummy & Degree from university or polytechnic \\
\hline \multicolumn{3}{|c|}{ Proxies for degree of information and experience } \\
\hline Economics/business & Dummy & $\begin{array}{l}\text { Tertiary education in business administration or eco- } \\
\text { nomics }\end{array}$ \\
\hline $\begin{array}{l}\text { Self-employed } \\
\text { "Freiberufler" }\end{array}$ & Dummy & $\begin{array}{l}\text { Last professional position as an independent lawyer, } \\
\text { tax advisor or in a similar self-employed occupation }\end{array}$ \\
\hline Years in Bundestag & $\begin{array}{l}\text { Discrete } \\
\text { variable }\end{array}$ & $\begin{array}{l}\text { Calculated as } 2007 \text { minus year of Bundestag entry, } \\
\text { interruptions are taken into account }\end{array}$ \\
\hline $\begin{array}{l}\text { Member financial } \\
\text { committee }\end{array}$ & Dummy & Deals with tax policy, financial markets, monetary policy \\
\hline $\begin{array}{l}\text { Member budget } \\
\text { committee }\end{array}$ & Dummy & $\begin{array}{l}\text { Deals with federal government budget, in particular } \\
\text { expenditure side }\end{array}$ \\
\hline \multicolumn{3}{|r|}{ Other variables } \\
\hline Eastern Germany & Dummy & $\begin{array}{l}\text { Member of parliament from a district or a party list in } \\
\text { Eastern Germany }\end{array}$ \\
\hline Female & Dummy & \\
\hline Party list & Dummy & $\begin{array}{l}\text { Not elected directly from a district but qualified for } \\
\text { Bundestag by position on a party list }\end{array}$ \\
\hline Age & $\begin{array}{l}\text { Discrete } \\
\text { variable }\end{array}$ & Calculated as 2007 minus year of birth \\
\hline \multicolumn{3}{|r|}{ State characteristics } \\
\hline Unemployment rate & $\begin{array}{l}\text { Continuous } \\
\text { variable }\end{array}$ & $\begin{array}{l}\text { in } \% \text { for the year 2006, source: German Statistical Of- } \\
\text { fice }\end{array}$ \\
\hline GDP per capita & $\begin{array}{l}\text { Continuous } \\
\text { variable }\end{array}$ & $\begin{array}{l}\text { In Euro for the year 2006, source: German Statistical } \\
\text { Office }\end{array}$ \\
\hline
\end{tabular}

Sources: Bundestag if no other source is named. 
Table 3: Survey results by party membership

\begin{tabular}{|c|c|c|c|c|c|}
\hline & Observations & Mean & Std. Dev. & Min & $\operatorname{Max}$ \\
\hline \multicolumn{6}{|c|}{ Q1 Real corporate mobility } \\
\hline FDP & 32 & 7.41 & 1.36 & 3 & 9 \\
\hline CDU/CSU & 53 & 6.68 & 1.48 & 3 & 9 \\
\hline SPD & 33 & 5.76 & 1.52 & 2 & 9 \\
\hline Greens & 12 & 4.67 & 1.50 & 3 & 8 \\
\hline Left Party & 27 & 3.93 & 1.47 & 2 & 8 \\
\hline Total & 157 & 6.01 & 1.88 & 2 & 9 \\
\hline \multicolumn{6}{|c|}{ Anova, F-Test p-value: 0.000} \\
\hline \multicolumn{6}{|c|}{ Q2 Profit shifting } \\
\hline FDP & 31 & 5.81 & 1.60 & 3 & 8 \\
\hline CDU/CSU & 53 & 6.21 & 1.54 & 3 & 9 \\
\hline SPD & 33 & 7.55 & 1.52 & 2 & 9 \\
\hline Greens & 12 & 7.00 & 1.04 & 5 & 8 \\
\hline Left Party & 27 & 7.07 & 1.88 & 3 & 9 \\
\hline Total & 156 & 6.62 & 1.69 & 2 & 9 \\
\hline \multicolumn{6}{|c|}{ Anova, F-Test p-value: 0.000} \\
\hline \multicolumn{6}{|c|}{ Q3 Voter awareness } \\
\hline FDP & 32 & 4.50 & 2.66 & 1 & 9 \\
\hline CDU/CSU & 53 & 4.25 & 1.95 & 1 & 9 \\
\hline SPD & 33 & 3.55 & 1.94 & 1 & 8 \\
\hline Greens & 12 & 4.08 & 2.07 & 1 & 7 \\
\hline Left Party & 27 & 4.19 & 1.78 & 1 & 7 \\
\hline Total & 157 & 4.13 & 2.09 & 1 & 9 \\
\hline \multicolumn{6}{|c|}{ Anova, F-Test p-value: 0.444} \\
\hline \multicolumn{6}{|c|}{ Q4 National autonomy } \\
\hline FDP & 32 & 6.53 & 1.67 & 2 & 9 \\
\hline CDU/CSU & 53 & 6.72 & 1.56 & 3 & 9 \\
\hline SPD & 33 & 5.94 & 1.20 & 3 & 7 \\
\hline Greens & 12 & 6.50 & 0.67 & 6 & 8 \\
\hline Left Party & 27 & 7.37 & 1.71 & 2 & 9 \\
\hline Total & 157 & 6.61 & 1.54 & 2 & 9 \\
\hline \multicolumn{6}{|c|}{ Anova, F-Test p-value: 0.009} \\
\hline \multicolumn{6}{|c|}{ Q5 EU minimum taxes } \\
\hline FDP & 32 & 2.50 & 2.36 & 1 & 8 \\
\hline CDU/CSU & 52 & 4.48 & 2.75 & 1 & 9 \\
\hline SPD & 33 & 7.82 & 1.76 & 3 & 9 \\
\hline Greens & 12 & 7.33 & 1.07 & 5 & 9 \\
\hline Left Party & 26 & 8.35 & 0.98 & 6 & 9 \\
\hline Total & 155 & 5.65 & 3.08 & 1 & 9 \\
\hline \multicolumn{6}{|c|}{ Anova, F-Test p-value: 0.000} \\
\hline \multicolumn{6}{|c|}{ Q6 Equity } \\
\hline FDP & 32 & 5.38 & 2.04 & 1 & 9 \\
\hline CDU/CSU & 52 & 6.81 & 1.63 & 3 & 9 \\
\hline SPD & 33 & 7.61 & 1.64 & 3 & 9 \\
\hline Greens & 12 & 7.67 & 1.07 & 6 & 9 \\
\hline Left Party & 27 & 8.59 & 0.64 & 7 & 9 \\
\hline Total & 156 & 7.06 & 1.88 & 1 & 9 \\
\hline \multicolumn{6}{|c|}{ Anova, F-Test p-value: 0.000} \\
\hline
\end{tabular}


Table 4: Ordered probit estimation: Tax policy restrictions

\begin{tabular}{|c|c|c|c|c|c|c|}
\hline \multirow[b]{2}{*}{ Variable } & \multicolumn{2}{|c|}{$\begin{array}{l}\text { Q1: Mobility real capital } \\
\text { Model 1a }\end{array}$} & \multicolumn{2}{|c|}{$\begin{array}{l}\text { Q2: Mobility paper profits } \\
\text { Model 1b }\end{array}$} & \multicolumn{2}{|c|}{$\begin{array}{c}\text { Q3: Yardstick competition } \\
\text { Model 1c }\end{array}$} \\
\hline & Coefficient & Marginal effect* & Coefficient & Marginal effect* & Coefficient & Marginal effect* \\
\hline \multicolumn{7}{|c|}{ Education } \\
\hline Secondary ("Abitur") & $\begin{array}{l}0.363^{* *} \\
(0.156)\end{array}$ & 0.053 & $\begin{array}{c}0.237 \\
(0.306)\end{array}$ & 0.007 & $\begin{array}{c}0.055 \\
(0.215)\end{array}$ & -0.013 \\
\hline Tertiary & $\begin{array}{c}0.135 \\
(0.216)\end{array}$ & 0.019 & $\begin{array}{l}-0.222 \\
(0.594)\end{array}$ & 0.003 & $\begin{array}{l}-0.228 \\
(0.231)\end{array}$ & 0.053 \\
\hline \multicolumn{7}{|c|}{ Information } \\
\hline Economic/business & $\begin{array}{l}-0.145 \\
(0.461)\end{array}$ & -0.020 & $\begin{array}{l}-0.181 \\
(0.139)\end{array}$ & -0.004 & $\begin{array}{l}-0.036 \\
(0.255)\end{array}$ & 0.008 \\
\hline "Freiberufler" & $\begin{array}{c}-0.373^{\star \star \star} \\
(0.129) \\
\end{array}$ & -0.055 & $\begin{array}{l}0.394^{\star \star \star} \\
(0.135) \\
\end{array}$ & -0.012 & $\begin{array}{l}0.263^{\star \star} \\
(0.134)\end{array}$ & -0.061 \\
\hline Years in Bundestag & $\begin{array}{l}0.055^{\star \star \star} \\
(0.014)\end{array}$ & 0.007 & $\begin{array}{l}-0.042^{\star \star \star} \\
(0.011)\end{array}$ & 0.000 & $\begin{array}{l}-0.003 \\
(0.016)\end{array}$ & 0.001 \\
\hline $\begin{array}{l}\text { Member financial } \\
\text { committee }\end{array}$ & $\begin{array}{l}0.457^{* \star *} \\
(0.127)\end{array}$ & 0.051 & $\begin{array}{l}-0.107 \\
(0.160)\end{array}$ & -0.002 & $\begin{array}{l}0.182^{\star} \\
(0.109)\end{array}$ & -0.043 \\
\hline $\begin{array}{l}\text { Member budget } \\
\text { committee }\end{array}$ & $\begin{array}{l}-0.300 \\
(0.261)\end{array}$ & -0.043 & $\begin{array}{c}0.341 \\
(0.392) \\
\end{array}$ & -0.008 & $\begin{array}{l}-0.030 \\
(0.140)\end{array}$ & 0.007 \\
\hline \multicolumn{7}{|c|}{ Other individual characteristics } \\
\hline Eastern Germany & $\begin{array}{c}0.301 \\
(0.241)\end{array}$ & 0.037 & $\begin{array}{c}-0.779 \star \star \star \star \\
(0.200)\end{array}$ & -0.061 & $\begin{array}{l}0.688^{\star \star \star} \\
(0.221)\end{array}$ & -0.150 \\
\hline Female & $\begin{array}{l}0.583^{\star \star \star} \\
(0.203)\end{array}$ & 0.067 & $\begin{array}{c}0.273 \\
(0.169) \\
\end{array}$ & -0.002 & $\begin{array}{c}0.157 \\
(0.161) \\
\end{array}$ & -0.037 \\
\hline Party list & $\begin{array}{l}-0.283^{\star \star} \\
(0.116)\end{array}$ & -0.038 & $\begin{array}{l}-0.062 \\
(0.098)\end{array}$ & -0.001 & $\begin{array}{l}-0.439 * * \\
(0.203)\end{array}$ & 0.102 \\
\hline Age & $\begin{array}{l}-0.016^{\star *} \\
(0.008)\end{array}$ & -0.002 & $\begin{array}{c}0.006 \\
(0.007)\end{array}$ & 0.000 & $\begin{array}{c}0.004 \\
(0.008)\end{array}$ & -0.001 \\
\hline \multicolumn{7}{|c|}{ State characteristics } \\
\hline Unemployment rate & $\begin{array}{c}0.020 \\
(0.023) \\
\end{array}$ & 0.003 & $\begin{array}{c}0.101 \\
(0.078) \\
\end{array}$ & 0.001 & $\begin{array}{l}-0.060^{*} \\
(0.036)\end{array}$ & 0.014 \\
\hline GDP per capita & $\begin{array}{c}0.000 \\
(0.000)\end{array}$ & 0.000 & $\begin{array}{c}0.000 \\
(0.000)\end{array}$ & 0.000 & $\begin{array}{c}0.000 \\
(0.000)\end{array}$ & 0.000 \\
\hline
\end{tabular}




\begin{tabular}{|c|c|c|c|c|c|c|}
\hline \multicolumn{7}{|c|}{ Party } \\
\hline CDU/CSU & $\begin{array}{l}-0.795^{\star \star \star} \\
(0.076)\end{array}$ & -0.110 & $\begin{array}{c}0.170 \\
(0.169)\end{array}$ & 0.000 & $\begin{array}{l}-0.276^{\star \star} \\
(0.108)\end{array}$ & 0.065 \\
\hline SPD & $\begin{array}{l}-1.522^{\star \star \star} \\
(0.156)\end{array}$ & -0.190 & $\begin{array}{l}1.155^{\star \star \star} \\
(0.226)\end{array}$ & -0.036 & $\begin{array}{l}-0.656^{\star \star \star} \\
(0.101)\end{array}$ & 0.149 \\
\hline GREENS & $\begin{array}{c}-2.215^{\star \star \star} \\
(0.128)\end{array}$ & -0.235 & $\begin{array}{c}0.501^{\star * *} \\
(0.094)\end{array}$ & -0.025 & $\begin{array}{c}-0.363^{\star \star \star} \\
(0.102) \\
\end{array}$ & 0.083 \\
\hline LEFT PARTY & $\begin{array}{l}-2.856^{\star \star \star} \\
(0.274)\end{array}$ & -0.248 & $\begin{array}{l}1.019^{\star \star \star} \\
(0.247)\end{array}$ & -0.096 & $\begin{array}{l}-0.034 \\
(0.209)\end{array}$ & 0.008 \\
\hline \multicolumn{7}{|c|}{ Regression diagnostics } \\
\hline $\begin{array}{l}p \text {-value joint signifi- } \\
\text { cance of variables }\end{array}$ & \multicolumn{2}{|c|}{0.000} & \multicolumn{2}{|c|}{0.068} & \multicolumn{2}{|c|}{0.000} \\
\hline $\begin{array}{l}\text { p-value joint signifi- } \\
\text { cance party dum- } \\
\text { mies }\end{array}$ & \multicolumn{2}{|c|}{0.000} & \multicolumn{2}{|c|}{0.000} & \multicolumn{2}{|c|}{0.000} \\
\hline Observations & \multicolumn{2}{|c|}{157} & \multicolumn{2}{|c|}{156} & \multicolumn{2}{|c|}{157} \\
\hline $\begin{array}{l}\text { Share correct } \\
\text { classifications } \\
\text { (exact hit/absolute } \\
\text { classification error } \\
<=1 \text { ) }\end{array}$ & \multicolumn{2}{|c|}{$0.261 / 0.745$} & \multicolumn{2}{|c|}{$0.244 / 0.718$} & \multicolumn{2}{|c|}{$0.204 / 0.484$} \\
\hline Pseudo-R2 & \multicolumn{2}{|c|}{0.130} & \multicolumn{2}{|c|}{0.090} & \multicolumn{2}{|c|}{0.026} \\
\hline
\end{tabular}

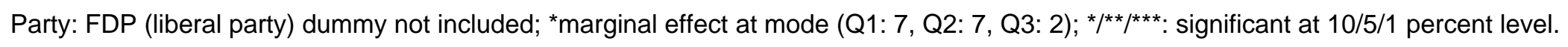


Table 5: Ordered probit estimation: Tax policy

\begin{tabular}{|c|c|c|c|c|}
\hline \multirow[b]{2}{*}{ Variable } & \multicolumn{2}{|c|}{$\begin{array}{l}\text { Q4: Autonomy of tax policy } \\
\text { Model } 2 \mathrm{a}\end{array}$} & \multicolumn{2}{|c|}{$\begin{array}{l}\text { Q5: Preference minimum taxes } \\
\text { Model } 2 b\end{array}$} \\
\hline & Coefficient & Marginal effect* & Coefficient & Marginal effect* \\
\hline \multicolumn{5}{|c|}{$\begin{array}{l}\text { Perceived restrictions } \\
\end{array}$} \\
\hline Real mobility (Q1) & $\begin{array}{l}0.196^{\star} \\
(0.113) \\
\end{array}$ & 0.025 & $\begin{array}{l}-0.100 \\
(0.062) \\
\end{array}$ & -0.025 \\
\hline Paper profits (Q2) & $\begin{array}{l}-0.073^{\star *} \\
(0.033)\end{array}$ & -0.009 & $\begin{array}{l}0.177^{\star \star} \\
(0.089)\end{array}$ & 0.044 \\
\hline Yardstick (Q3) & $\begin{array}{c}0.012 \\
(0.052)\end{array}$ & 0.002 & $\begin{array}{l}-0.045 \\
(0.071) \\
\end{array}$ & -0.011 \\
\hline \multicolumn{5}{|c|}{ Education } \\
\hline Secondary (“Abitur") & $\begin{array}{l}-0.414^{\star \star \star} \\
(0.150)\end{array}$ & -0.036 & $\begin{array}{l}-0.442^{\star} \\
(0.232) \\
\end{array}$ & -0.123 \\
\hline Tertiary & $\begin{array}{c}0.669 * * \star \\
(0.150)\end{array}$ & 0.123 & $\begin{array}{l}-0.130 \\
(0.407) \\
\end{array}$ & -0.034 \\
\hline \multicolumn{5}{|c|}{ Information } \\
\hline Economic/business & $\begin{array}{c}0.185 \\
(0.158) \\
\end{array}$ & 0.021 & $\begin{array}{c}0.007 \\
(0.230) \\
\end{array}$ & 0.002 \\
\hline "Freiberufler" & $\begin{array}{c}0.143 \\
(0.267)\end{array}$ & 0.016 & $\begin{array}{l}0.382^{\star \star \star} \\
(0.086)\end{array}$ & 0.107 \\
\hline Years in Bundestag & $\begin{array}{l}-0.031 \\
(0.025) \\
\end{array}$ & -0.004 & $\begin{array}{l}-0.040^{\star *} \\
(0.016)\end{array}$ & -0.010 \\
\hline $\begin{array}{l}\text { Member financial com- } \\
\text { mittee }\end{array}$ & $\begin{array}{c}0.168 \\
(0.283) \\
\end{array}$ & 0.019 & $\begin{array}{l}-0.229 \\
(0.223) \\
\end{array}$ & -0.053 \\
\hline $\begin{array}{l}\text { Member budget commit- } \\
\text { tee }\end{array}$ & $\begin{array}{l}0.245^{\star} \\
(0.139) \\
\end{array}$ & 0.025 & $\begin{array}{l}-0.404^{*} \\
(0.220) \\
\end{array}$ & -0.088 \\
\hline \multicolumn{5}{|c|}{ Other individual characteristics } \\
\hline Eastern Germany & $\begin{array}{l}-0.403^{\star} \\
(0.220)\end{array}$ & -0.067 & $\begin{array}{l}-0.046 \\
(0.318) \\
\end{array}$ & -0.011 \\
\hline Female & $\begin{array}{l}-0.022 \\
(0.162)\end{array}$ & -0.003 & $\begin{array}{l}-0.178 \\
(0.119)\end{array}$ & -0.043 \\
\hline Party list & $\begin{array}{l}-0.012 \\
(0.284) \\
\end{array}$ & -0.002 & $\begin{array}{l}-0.584^{\star \star \star} \\
(0.137)\end{array}$ & -0.148 \\
\hline Age & $\begin{array}{c}0.009 \\
(0.014)\end{array}$ & 0.001 & $\begin{array}{c}0.019 \\
(0.014)\end{array}$ & 0.005 \\
\hline
\end{tabular}




\begin{tabular}{|c|c|c|c|c|}
\hline \multicolumn{5}{|c|}{ State characteristics } \\
\hline Unemployment rate & $\begin{array}{c}0.071 \\
(0.059)\end{array}$ & 0.009 & $\begin{array}{l}0.113^{\star} \\
(0.068)\end{array}$ & 0.028 \\
\hline GDP per capita & $\begin{array}{c}0.000 \\
(0.000) \\
\end{array}$ & 0.000 & $\begin{array}{l}0.000^{\star \star} \\
(0.000)\end{array}$ & 0.000 \\
\hline \multicolumn{5}{|c|}{ Party } \\
\hline CDU/CSU & $\begin{array}{l}0.362^{\star} \\
(0.204)\end{array}$ & 0.040 & $\begin{array}{l}0.563^{\star \star \star} \\
(0.113)\end{array}$ & 0.150 \\
\hline SPD & $\begin{array}{c}0.013 \\
(0.177) \\
\end{array}$ & 0.002 & $\begin{array}{l}2.038^{\star \star \star} \\
(0.115)\end{array}$ & 0.582 \\
\hline GREENS & $\begin{array}{c}0.438 \\
(0.379) \\
\end{array}$ & 0.028 & $\begin{array}{l}1.835^{\star \star \star} \\
(0.266)\end{array}$ & 0.630 \\
\hline LEFT PARTY & $\begin{array}{l}1.460^{\star \star *} \\
(0.344)\end{array}$ & -0.107 & $\begin{array}{l}2.666^{\star \star \star} \\
(0.244)\end{array}$ & 0.814 \\
\hline \multicolumn{5}{|c|}{ Regression diagnostics } \\
\hline $\begin{array}{l}p \text {-value joint significance } \\
\text { of variables }\end{array}$ & \multicolumn{2}{|c|}{0.000} & \multicolumn{2}{|c|}{0.000} \\
\hline $\begin{array}{l}\text { p-value joint significance } \\
\text { party dummies }\end{array}$ & \multicolumn{2}{|c|}{0.000} & \multicolumn{2}{|c|}{0.000} \\
\hline Observations & \multicolumn{2}{|c|}{156} & \multicolumn{2}{|c|}{154} \\
\hline $\begin{array}{l}\text { Share correct } \\
\text { classifications } \\
\text { (exact hit/absolute classi- } \\
\text { fication error }<=1 \text { ) }\end{array}$ & \multicolumn{2}{|c|}{$0.376 / 0.732$} & \multicolumn{2}{|c|}{$0.413 / 0.671$} \\
\hline Pseudo-R2 & \multicolumn{2}{|c|}{0.081} & \multicolumn{2}{|c|}{0.208} \\
\hline
\end{tabular}

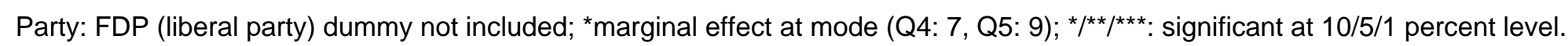


Table 6: Ordered probit estimation control group: Tax policy restrictions

\begin{tabular}{|c|c|c|c|c|c|c|}
\hline \multirow[b]{2}{*}{ Variable } & \multicolumn{2}{|c|}{$\begin{array}{c}\text { Q1: Mobility real capital } \\
\text { Model 1a }\end{array}$} & \multicolumn{2}{|c|}{$\begin{array}{c}\text { Q2: Mobility paper profits } \\
\text { Model 1b }\end{array}$} & \multicolumn{2}{|c|}{$\begin{array}{c}\text { Q3: Yardstick competition } \\
\text { Model 1c }\end{array}$} \\
\hline & Coefficient & Marginal effect* & Coefficient & Marginal effect* & Coefficient & Marginal effect* \\
\hline \multicolumn{7}{|c|}{ Information } \\
\hline Public finance lecture & $\begin{array}{l}-0.341 \\
(0.288)\end{array}$ & 0.026 & $\begin{array}{c}-0.891^{* \star *} \\
(0.185)\end{array}$ & 0.039 & $\begin{array}{l}-0.208 \\
(0.285)\end{array}$ & 0.027 \\
\hline Number of semesters & $\begin{array}{l}0.234^{\star \star} \\
(0.098)\end{array}$ & -0.015 & $\begin{array}{c}0.083 \\
(0.100) \\
\end{array}$ & -0.001 & $\begin{array}{c}0.150 \\
(0.166)\end{array}$ & -0.019 \\
\hline \multicolumn{7}{|c|}{ Other individual characteristics } \\
\hline German & $\begin{array}{c}0.117 \\
(0.293) \\
\end{array}$ & -0.006 & $\begin{array}{c}0.276 \\
(0.171) \\
\end{array}$ & 0.203 & $\begin{array}{l}-0.021 \\
(0.530)\end{array}$ & 0.702 \\
\hline Female & $\begin{array}{l}0.559 * \\
(0.312)\end{array}$ & -0.054 & $\begin{array}{c}0.291^{\star \star \star} \\
(0.111)\end{array}$ & $0.413^{\star \star \star}$ & $\begin{array}{c}-0.057^{\star \star \star} \\
(0.109)\end{array}$ & 0.000 \\
\hline \multicolumn{7}{|c|}{ Party } \\
\hline CDU/CSU & $\begin{array}{l}-0.192^{\star \star} \\
(0.086)\end{array}$ & 0.009 & $\begin{array}{c}-0.489^{\star \star \star} \\
(0.103)\end{array}$ & -0.014 & $\begin{array}{c}0.197 \\
(0.185) \\
\end{array}$ & -0.027 \\
\hline SPD & $\begin{array}{l}-0.426^{\star \star \star} \\
(0.056)\end{array}$ & 0.018 & $\begin{array}{c}0.007 \\
(0.053)\end{array}$ & 0.000 & $\begin{array}{l}0.384^{\star \star \star} \\
(0.117)\end{array}$ & -0.052 \\
\hline GREENS & $\begin{array}{c}-0.427^{\star \star \star} \\
(0.112) \\
\end{array}$ & 0.002 & $\begin{array}{l}-0.993^{\star \star \star} \\
(0.153)\end{array}$ & -0.104 & $\begin{array}{c}0.804^{\star \star \star} \\
(0.275)\end{array}$ & -0.137 \\
\hline LEFT PARTY & $\begin{array}{l}-1.484^{\star \star \star} \\
(0.263)\end{array}$ & -0.189 & $\begin{array}{c}-0.802^{\star \star \star} \\
(0.283)\end{array}$ & -0.082 & $\begin{array}{l}-0.351 \\
(0.373)\end{array}$ & 0.028 \\
\hline \multicolumn{7}{|c|}{ Regression diagnostics } \\
\hline $\begin{array}{l}\mathrm{p} \text {-value joint significance } \\
\text { of variables }\end{array}$ & \multicolumn{2}{|c|}{0.000} & \multicolumn{2}{|c|}{0.000} & \multicolumn{2}{|c|}{0.000} \\
\hline $\begin{array}{l}\text { p-value joint significance } \\
\text { party dummies }\end{array}$ & \multicolumn{2}{|c|}{0.000} & \multicolumn{2}{|c|}{0.000} & \multicolumn{2}{|c|}{0.000} \\
\hline Observations & \multicolumn{2}{|c|}{72} & \multicolumn{2}{|c|}{72} & \multicolumn{2}{|c|}{72} \\
\hline $\begin{array}{l}\text { Share correct } \\
\text { classifications } \\
\text { (exact hit/absolute clas- } \\
\text { sification error <=1) }\end{array}$ & \multicolumn{2}{|c|}{$0.325 / 0.554$} & \multicolumn{2}{|c|}{$0.349 / 0.675$} & \multicolumn{2}{|c|}{$0.277 / 0.506$} \\
\hline Pseudo-R2 & \multicolumn{2}{|c|}{0.038} & \multicolumn{2}{|c|}{0.061} & \multicolumn{2}{|c|}{0.029} \\
\hline
\end{tabular}

Party: FDP (liberal party) dummy not included; *marginal effect at mode (Q1: 6, Q2: 7, Q3: 3); ***/***: significant at 10/5/1 percent level. 
Table 7: Ordered probit estimation control group: Tax policy

\begin{tabular}{|c|c|c|c|c|}
\hline \multirow[b]{2}{*}{ Variable } & \multicolumn{2}{|c|}{$\begin{array}{l}\text { Q4: Autonomy of tax policy } \\
\text { Model 2a }\end{array}$} & \multicolumn{2}{|c|}{$\begin{array}{l}\text { Q5: Preference minimum taxes } \\
\text { Model 2b }\end{array}$} \\
\hline & Coefficient & Marginal effect* & Coefficient & Marginal effect* \\
\hline \multicolumn{5}{|c|}{ Perceived restrictions } \\
\hline Real mobility (Q1) & $\begin{array}{l}-0.033 \\
(0.103)\end{array}$ & -0.003 & $\begin{array}{c}0.018 \\
(0.100)\end{array}$ & -0.003 \\
\hline Paper profits (Q2) & $\begin{array}{l}-0.012 \\
(0.070)\end{array}$ & -0.001 & $\begin{array}{c}0.004 \\
(0.134)\end{array}$ & -0.001 \\
\hline Yardstick (Q3) & $\begin{array}{l}-0.002 \\
(0.031)\end{array}$ & 0.000 & $\begin{array}{l}-0.052 \\
(0.062)\end{array}$ & 0.007 \\
\hline \multicolumn{5}{|c|}{ Information } \\
\hline Public finance lecture & $\begin{array}{l}0.668^{*} \\
(0.400)\end{array}$ & 0.060 & $\begin{array}{l}-0.052 \\
(0.428)\end{array}$ & 0.007 \\
\hline Number of semesters & $\begin{array}{l}-0.166^{\star \star} \\
(0.075)\end{array}$ & -0.013 & $\begin{array}{l}-0.059 \\
(0.134)\end{array}$ & 0.008 \\
\hline \multicolumn{5}{|c|}{ Other individual characteristics } \\
\hline German & $\begin{array}{c}0.205 \\
(0.539)\end{array}$ & 0.020 & $\begin{array}{l}0.622^{\star} \\
(0.336)\end{array}$ & -0.061 \\
\hline Female & $\begin{array}{l}-0.085 \\
(0.475)\end{array}$ & -0.007 & $\begin{array}{l}-0.218 \\
(0.553)\end{array}$ & 0.030 \\
\hline \multicolumn{5}{|c|}{ Party preference } \\
\hline CDU/CSU & $\begin{array}{l}0.227^{\star \star \star} \\
(0.055)\end{array}$ & 0.014 & $\begin{array}{c}0.214 \\
(0.311)\end{array}$ & -0.032 \\
\hline SPD & $\begin{array}{l}0.395^{\star \star \star} \\
(0.098)\end{array}$ & 0.024 & $\begin{array}{l}1.430^{\star \star \star} \\
(0.277)\end{array}$ & -0.195 \\
\hline GREENS & $\begin{array}{l}-0.543^{* * *} \\
(0.098)\end{array}$ & -0.065 & $\begin{array}{l}1.110^{* *} \\
(0.565)\end{array}$ & -0.167 \\
\hline LEFT PARTY & $\begin{array}{l}-1.551^{\star \star \star} \\
(0.302)\end{array}$ & -0.212 & $\begin{array}{l}-0.201^{*} \\
(0.111)\end{array}$ & 0.026 \\
\hline \multicolumn{5}{|c|}{ Regression diagnostics } \\
\hline $\begin{array}{l}\text { p-value joint significance } \\
\text { of variables }\end{array}$ & \multicolumn{2}{|c|}{0.000} & \multicolumn{2}{|c|}{0.000} \\
\hline $\begin{array}{l}\text { p-value joint significance } \\
\text { party dummies }\end{array}$ & \multicolumn{2}{|c|}{0.000} & \multicolumn{2}{|c|}{0.000} \\
\hline Observations & \multicolumn{2}{|c|}{72} & \multicolumn{2}{|c|}{72} \\
\hline $\begin{array}{l}\text { Share correct } \\
\text { classifications } \\
\text { (exact hit/absolute classi- } \\
\text { fication error }<=1 \text { ) }\end{array}$ & \multicolumn{2}{|c|}{$0.229 / 0.518$} & \multicolumn{2}{|c|}{$0.244 / 0.439$} \\
\hline Pseudo-R2 & \multicolumn{2}{|c|}{0.056} & \multicolumn{2}{|c|}{0.076} \\
\hline
\end{tabular}

Party: FDP (liberal party) dummy not included; *marginal effect at mode (Q4: 6, Q5: 3); $* / \star \star / \star \star *$ : significant at 10/5/1 percent level. 
Table 8: Ordered probit estimation for Q6 - equity and company taxation

\begin{tabular}{|c|c|c|}
\hline Variable & Coefficient & Marginal effect* \\
\hline \multicolumn{3}{|c|}{ Education } \\
\hline Secondary ("Abitur") & $\begin{array}{c}-0.497^{\star \star \star} \\
(0.179)\end{array}$ & -0.163 \\
\hline Tertiary & $\begin{array}{c}0.094 \\
(0.149) \\
\end{array}$ & 0.028 \\
\hline \multicolumn{3}{|c|}{ Information } \\
\hline Economic/business & $\begin{array}{l}-0.445 \\
(0.346)\end{array}$ & -0.120 \\
\hline "Freiberufler" & $\begin{array}{l}-0.219 \\
(0.220)\end{array}$ & -0.062 \\
\hline Years in Bundestag & $\begin{array}{l}-0.032 \\
(0.027)\end{array}$ & -0.010 \\
\hline $\begin{array}{l}\text { Member financial com- } \\
\text { mittee }\end{array}$ & $\begin{array}{l}0.489^{\star \star} \\
(0.227)\end{array}$ & 0.161 \\
\hline $\begin{array}{l}\text { Member budget commit- } \\
\text { tee }\end{array}$ & $\begin{array}{l}-0.277 \\
(0.314)\end{array}$ & -0.077 \\
\hline \multicolumn{3}{|c|}{ Other individual characteristics } \\
\hline Eastern Germany & $\begin{array}{l}-0.211 \\
(0.193)\end{array}$ & -0.060 \\
\hline Female & $\begin{array}{l}0.318^{\star \star} \\
(0.146)\end{array}$ & 0.100 \\
\hline Party list & $\begin{array}{l}-0.221^{\star \star \star} \\
(0.053)\end{array}$ & -0.067 \\
\hline Age & $\begin{array}{c}0.005 \\
(0.009)\end{array}$ & 0.002 \\
\hline \multicolumn{3}{|c|}{ State characteristics } \\
\hline Unemployment rate & $\begin{array}{c}0.067 \\
(0.057) \\
\end{array}$ & 0.020 \\
\hline GDP per capita & $\begin{array}{c}0.000 \\
(0.000) \\
\end{array}$ & 0.000 \\
\hline \multicolumn{3}{|c|}{ Party } \\
\hline CDU/CSU & $\begin{array}{l}0.816 * \star \star \\
(0.096)\end{array}$ & 0.260 \\
\hline SPD & $\begin{array}{l}1.040 * \star \star \\
(0.131)\end{array}$ & 0.334 \\
\hline GREENS & $\begin{array}{c}1.408^{\star * *} \\
0.156)\end{array}$ & 0.513 \\
\hline LEFT PARTY & $\begin{array}{c}2.076^{\star \star \star} \\
(0.200)\end{array}$ & 0.698 \\
\hline \multicolumn{3}{|c|}{$\begin{array}{r}\text { Regression diagnostics } \\
\end{array}$} \\
\hline $\begin{array}{l}\text { p-value joint significance } \\
\text { of variables }\end{array}$ & \multicolumn{2}{|c|}{0.000} \\
\hline $\begin{array}{l}\text { p-value joint significance } \\
\text { party dummies }\end{array}$ & \multicolumn{2}{|c|}{0.000} \\
\hline Observations & \multicolumn{2}{|c|}{156} \\
\hline $\begin{array}{l}\text { Share correct } \\
\text { classifications } \\
\text { (exact hit/absolute clas- } \\
\text { sification error }<=1 \text { ) }\end{array}$ & \multicolumn{2}{|c|}{$0.365 / 0.654$} \\
\hline Pseudo-R2 & \multicolumn{2}{|c|}{0.100} \\
\hline
\end{tabular}

Party: FDP (liberal party) dummy not included; *marginal effect at mode (9); $\star / \star \star / * \star *$ : significant at 10/5/1 percent level. 
Table 9: Ordered probit estimation: Tax policy restrictions - robustness check without party dummies

\begin{tabular}{|c|c|c|c|c|c|c|}
\hline \multirow[b]{2}{*}{ Variable } & \multicolumn{2}{|c|}{$\begin{array}{l}\text { Q1: Mobility real capital } \\
\text { Model 1a }\end{array}$} & \multicolumn{2}{|c|}{$\begin{array}{l}\text { Q2: Mobility paper profits } \\
\text { Model 1b }\end{array}$} & \multicolumn{2}{|c|}{$\begin{array}{c}\text { Q3: Yardstick competition } \\
\text { Model 1c }\end{array}$} \\
\hline & Coefficient & Marginal effect* & Coefficient & Marginal effect* & Coefficient & Marginal effect* \\
\hline \multicolumn{7}{|c|}{ Education } \\
\hline Secondary (“Abitur") & $\begin{array}{c}0.328 \\
(0.262)\end{array}$ & 0.037 & $\begin{array}{c}0.243 \\
(0.237) \\
\end{array}$ & 0.007 & $\begin{array}{c}-0.007 \\
(0.227) \\
\end{array}$ & 0.002 \\
\hline Tertiary & $\begin{array}{c}0.149 \\
(0.209)\end{array}$ & 0.016 & $\begin{array}{l}-0.263 \\
(0.405)\end{array}$ & 0.003 & $\begin{array}{l}-0.198 \\
(0.223)\end{array}$ & 0.046 \\
\hline \multicolumn{7}{|c|}{ Information } \\
\hline "Freiberufler" & $\begin{array}{c}0.014 \\
(0.123)\end{array}$ & 0.001 & $\begin{array}{c}0.210 \\
(0.159)\end{array}$ & -0.002 & $\begin{array}{l}0.318^{\star *} \\
(0.137)\end{array}$ & -0.072 \\
\hline Years in Bundestag & $\begin{array}{l}0.052^{\star \star \star} \\
(0.015)\end{array}$ & 0.005 & $\begin{array}{l}-0.040^{\star \star \star} \\
(0.013)\end{array}$ & 0.000 & $\begin{array}{l}-0.006 \\
(0.016)\end{array}$ & 0.001 \\
\hline $\begin{array}{l}\text { Member financial com- } \\
\text { mittee }\end{array}$ & $\begin{array}{l}0.398^{\star \star \star} \\
(0.142)\end{array}$ & 0.032 & $\begin{array}{l}-0.170 \\
(0.139)\end{array}$ & -0.004 & $\begin{array}{c}0.165 \\
(0.133)\end{array}$ & -0.038 \\
\hline $\begin{array}{l}\text { Member budget commit- } \\
\text { tee }\end{array}$ & $\begin{array}{l}-0.271 \\
(0.310)\end{array}$ & -0.030 & $\begin{array}{c}0.243 \\
(0.316)\end{array}$ & -0.002 & $\begin{array}{c}0.037 \\
(0.087)\end{array}$ & -0.009 \\
\hline \multicolumn{7}{|c|}{ Other individual characteristics } \\
\hline Eastern Germany & $\begin{array}{c}0.136 \\
(0.268) \\
\end{array}$ & 0.013 & $\begin{array}{c}-0.723^{\star \star \star} \\
(0.182)\end{array}$ & -0.051 & $\begin{array}{l}0.753^{\star \star \star} \\
(0.203)\end{array}$ & -0.160 \\
\hline Female & $\begin{array}{c}0.217 \\
(0.184)\end{array}$ & 0.020 & $\begin{array}{l}0.469 \star \star \star \\
(0.167)\end{array}$ & -0.005 & $\begin{array}{c}0.078 \\
(0.130)\end{array}$ & -0.018 \\
\hline Party list & $\begin{array}{l}-0.406 \\
(0.323)\end{array}$ & -0.039 & $\begin{array}{l}-0.057 \\
(0.145)\end{array}$ & -0.001 & $\begin{array}{l}-0.299^{\star *} \\
(0.130)\end{array}$ & 0.069 \\
\hline Age & $\begin{array}{l}-0.009 \\
(0.009)\end{array}$ & -0.001 & $\begin{array}{c}0.008 \\
(0.008)\end{array}$ & 0.000 & $\begin{array}{c}0.002 \\
(0.008)\end{array}$ & 0.000 \\
\hline
\end{tabular}


State characteristics

\begin{tabular}{|c|c|c|c|c|c|c|}
\hline \multicolumn{7}{|c|}{ State characteristics } \\
\hline Unemployment rate & $\begin{array}{c}0.008 \\
(0.016) \\
\end{array}$ & 0.001 & $\begin{array}{c}0.091 \\
(0.066) \\
\end{array}$ & 0.001 & $\begin{array}{l}-0.057^{*} \\
(0.033)\end{array}$ & 0.013 \\
\hline GDP per capita & $\begin{array}{c}0.000 \\
(0.000)\end{array}$ & 0.000 & $\begin{array}{c}0.000 \\
(0.000)\end{array}$ & 0.000 & $\begin{array}{l}0.000^{\star} \\
(0.000)\end{array}$ & 0.000 \\
\hline \multicolumn{7}{|c|}{ Regression diagnostics } \\
\hline $\begin{array}{l}\text { p-value joint significance } \\
\text { of variables }\end{array}$ & \multicolumn{2}{|c|}{0.000} & \multicolumn{2}{|c|}{0.000} & \multicolumn{2}{|c|}{0.000} \\
\hline Observations & \multicolumn{2}{|c|}{157} & \multicolumn{2}{|c|}{156} & \multicolumn{2}{|c|}{157} \\
\hline Pseudo-R2 & \multicolumn{2}{|c|}{$0.166 / 0.516$} & \multicolumn{2}{|c|}{0.045} & \multicolumn{2}{|c|}{0.016} \\
\hline
\end{tabular}

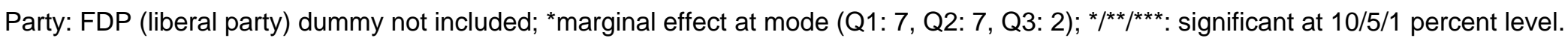

